\title{
OSIGURANJE PRIVREMENIM MJERAMA O OSTVARIVANJU RODITELJSKE SKRBI I OSOBNIH ODNOSA S DJETETOM - NEKI PRAVNI PRIJEPORI
}

\author{
Izv. prof. dr. sc. Slađana Aras Kramar*
}

\author{
UDK 347.637:347.952.2 \\ https://doi.org/10.30925/zpfsr.42.2.6 \\ Ur.: 26. veljače 2021. \\ Pr.: 22. ožujka 2021. \\ Prethodno priopćenje
}

\begin{abstract}
Sažetak
Donošenjem Obiteljskog zakona iz 2015. hrvatski se zakonodavac vratio normativnom pristupu Zakona o braku i porodičnim odnosima iz 1978., izričitim propisivanjem posebnih sudskih postupaka osiguranja privremenim mjerama o tome s kojim će roditeljem, odnosno drugom osobom dijete stanovati i o ostvarivanju osobnih odnosa s djetetom. Uz to, Zakonom su na obuhvatniji način propisana i pojedina opća pitanja uz određivanje osiguranja privremenim mjerama u obiteljskopravnim odnosima. Unatoč tomu, $i$ dalje se otvaraju određena načelno teorijska, ali i implementacijsko-praktična pitanja, posebice oko dopuštenosti ovoga provizornog pravozaštitnog puta u slučaju pravnih odnosa između roditelja i djece, a koja se nastoje analizirati i raspraviti u radu. U zaključnom dijelu daje se sinteza glavnih rezultata istraživanja.
\end{abstract}

Ključne riječi: postupak osiguranja; privremene mjere; roditeljska skrb; Obiteljski zakon; Ovršni zakon.

\section{UVOD: ODREĐENJE PREDMETA ISTRAŽIVANJA U POVIJESNOJ GENEZI}

Obiteljski zakon iz 2015. (dalje: ObZ 2015.), ${ }^{1}$ među posebnim postupcima osiguranja, propisuje postupke radi određivanja privremene mjere o tome s kojim će roditeljem, odnosno drugom osobom dijete stanovati i o ostvarivanju osobnih odnosa s djetetom, kao i privremene mjere radi uzdržavanja. Propisivanje osiguranja privremenom mjerom o tome s kojim će roditeljem, odnosno drugom osobom dijete stanovati i o ostvarivanju osobnih odnosa s djetetom, novina je u odnosu na uređenje posebnih obiteljskih postupaka osiguranja Obiteljskim zakonom iz 2003. (dalje: ObZ

* Dr. sc. Slađana Aras Kramar, izvanredna profesorica, Pravni fakultet Sveučilišta u Zagrebu; saras@pravo.hr. ORCID: https://orcid.org/0000-0002-8908-775X.

1 Obiteljski zakon iz 2015., Narodne novine, br. 103/15., 98/19., 47/20. - v. čl. 35. Zakona o Centru za posebno skrbništvo. 
2003.). ${ }^{2}$ Međutim, promatrajući povijesnu genezu propisivanja obiteljskih i statusnih sudskih postupaka, treba istaknuti da su u Zakonu o braku i porodičnim odnosima iz 1978. (dalje: ZBPO) ${ }^{3}$ te Obiteljskim zakonom iz 1998. (dalje: ObZ 1998.) bila sadržana pojedina rješenja u skladu s kojima su se provizorno mogli urediti, a time i osigurati odnosi roditelja i djece u okolnostima u kojima roditelji nisu živjeli zajedno te nisu bili postigli sporazum u odnosu na djecu.

Odredbama čl. 64. ZBPO-a bila je propisana nadležnost tadašnjega organa starateljstva da u postupku mirenja bračnih drugova ako je izostao sporazum u odnosu na djecu, odluči o čuvanju i odgoju djece ako je to s obzirom na okolnosti slučaja bilo potrebno. Pritom je to uređenje odnosa roditelja i djece bilo privremeno, odnosno ono je vrijedilo za vrijeme dok sud o tome nije donio odluku u postupku radi razvoda braka (čl. 64. st. 2. ZBPO). Odlukom organa starateljstva o povjeravanju djece na čuvanje i odgoj trebalo se odrediti i ostvarivanje osobnih odnosa roditelja s djecom. ${ }^{5}$ Uz to, ZBPO je sadržavao i odredbe o privremenoj mjeri radi smještaja djeteta u nadležnosti suda, koje su bile bitno novelirane izmjenama i dopunama toga Zakona iz 1989. (dalje: ZIDZBPO 1989.). ${ }^{6}$

Prema ZBPO-u nakon ZIDZBPO-a 1989., kao mjera osiguranja bila je uređena privremena mjera radi smještaja djeteta koju je sud mogao odrediti u svakom postupku u kojem se odlučivalo o pravima i interesima djece, pa i nakon što je bila donesena odluka suda o povjeravanju djeteta na čuvanje i odgoj koja još nije postala izvršna (prema tadašnjoj terminologiji) (čl. 395. ZBPO). Određujući pretpostavke ove regulacijske privremene mjere o smještaju djeteta, ZBPO je obuhvaćao posebnu odredbu prema kojoj se ona mogla odrediti ako bi se učinilo vjerojatnim da bi, ako se ta mjera ne bi bila odredila, mogli biti dovedeni u opasnost osobni ili drugi važni interesi djeteta ili da bi se bez tog osiguranja spriječilo ili znatno otežalo izvršenje odluke o predaji djeteta (čl. 387. ZBPO). Privremenom mjerom radi smještaja djeteta ono se moglo povjeriti roditelju, drugoj osobi ili ustanovi, a mogla se odrediti i svaka druga mjera kojom se postizalo svrha takvog osiguranja (čl. 400. st. 1. ZBPO). Uz to, sud je privremenom mjerom radi smještaja djeteta odlučivao i o održavanju osobnih odnosa roditelja s djetetom (čl. 400. st. 2. ZBPO). Izrijekom je bila propisana, nakon donošenja ZIDZBPO-a 1989., obveza suda da prije određivanja privremene mjere zatraži mišljenje ili stručnu pomoć organa starateljstva, osim ako je postojala opasnost od odgode (čl. 400. st. 3. ZBPO).

Obilježje važenja ZBPO-a, posebice nakon ZIDZBPO-a 1989., bilo je postojanje

2 Obiteljski zakon iz 2003., Narodne novine, br. 116/03., 17/04., 136/04., 107/07., 57/11. - v. čl.

52. Zakona o izmjenama i dopunama Zakona o parničnom postupku, 61/11., 25/13. - v. čl. 100.

Zakona o izmjenama i dopunama Zakona o parničnom postupku, 5/15. - v. Rješenje USRH, br. U-I-3101/2014 i dr. od 12. siječnja 2015.

3 Zakon o braku i porodičnim odnosima SR Hrvatske iz 1978., Narodne novine SRH, br. 11/78., 27/78. - ispravak, 45/89., 51/89. - pročišćeni tekst, 59/90.

4 Obiteljski zakon iz 1998., Narodne novine, br. 162/98.

5 Tako u Mira Alinčić i Ana Bakarić, Porodično pravo, 3. izd. (Zagreb: Narodne novine, 1989.), 94; Siniša Triva, Građansko parnično procesno pravo, 4. izd. (Zagreb: Narodne novine, 1980.), 618.

6 Zakon o izmjenama i dopunama Zakona o braku i porodičnim odnosima SR Hrvatske iz 1989., Narodne novine SRH, br. 45/89. 
nadležnosti organa starateljstva i suda za određivanje osiguranja privremenim mjerama o čuvanju i odgoju djeteta, odnosno njegovu smještaju i održavanju osobnih odnosa roditelja s djetetom. Pritom, promatrajući sudsku nadležnost za njezino određivanje, treba istaknuti da je ZBPO-om nakon ZIDZBPO-a 1989., izrijekom propisano određivanje privremene mjere radi smještaja djeteta $u$ incidentalnim adhezijskim postupcima uz postupak u kojima se odlučivalo o pravima $\mathrm{i}$ interesima djeteta, neovisno o prirodi glavnoga postupka (arg. ex čl. 395. st. 1. i 2., čl. 403. st. 2. ZBPO). Ona je pritom djelovala do okončanja sudskog postupka radi povjeravanja djeteta na čuvanje i odgoj, odnosno, ako je bila donesena u drugom sudskom postupku, do donošenja odluke organa starateljstva o čuvanju i odgoju djeteta, ili odgovarajuće mjere osiguranja u skladu s odredbama Zakona o općem upravnom postupku ${ }^{7}$ ( $\mathrm{arg}$. ex čl. 403. st. 2. u vezi s čl. 395. st. 1. ZBPO).

Različito od ZBPO-a, ObZ 1998. nije sadržavao slična rješenja o posebnim sudskim postupcima osiguranja privremenim mjerama o pojedinim sadržajima roditeljske skrbi, njezina ostvarivanja i ostvarivanja osobnih odnosa s djetetom. Taj je Zakon iz 1998., međutim, izrijekom propisivao nadležnost centra za socijalnu skrb da tijekom postupka posredovanja provizorno odluči o pitanjima s kojim će roditeljem dijete živjeti, o susretima i druženju s roditeljem s kojim neće živjeti (prema terminologiji ObZ-a 1998.), odnosno o smještaju djeteta tijekom postupka posredovanja ili tijekom trajanja postupka radi razvoda braka (čl. 49. st. 2.-4. ObZ 1998.). ${ }^{8}$

Donošenjem ObZ-a 2003. dolazi do prekida u kontinuitetu propisivanja nadležnosti centra za socijalnu skrb za provizorno uređenje pojedinih pitanja roditeljske skrbi i njezina ostvarivanja te ostvarivanja osobnih odnosa s djetetom tijekom tadašnjega postupka posredovanja. Prema odredbi čl. 46. st. 2. ObZ-a 2003., kad je primio tužbu ili sporazumni zahtjev radi razvoda braka, sud je bio obvezan ispitati stranke postoji li sporazum o tome s kojim će roditeljem dijete živjeti, o njegovim susretima i druženju s drugim roditeljem, odnosno o smještaju djeteta tijekom trajanja postupka radi razvoda braka. Međutim, ni ObZ 2003., kao ni prethodni Zakon iz 1998., nije posebno propisivao sudske postupke osiguranja privremenim mjerama o pojedinim sadržajima roditeljske skrbi, njezina ostvarivanja i ostvarivanja osobnih odnosa. Uz to, ObZ 2003. nije propisivao nadležnost centra za socijalnu skrb u provizornom uređenju odnosa roditelja i djece tijekom trajanja postupka radi razvoda braka. ${ }^{9}$

Iako ObZ 2003. nije izrijekom propisivao ni nadležnost sudova ni centra za socijalnu skrb za osiguranjem privremenim uređenjem odnosa roditelja i djece, u praksi su pojedini sudovi prihvaćali takvu nadležnost i određivali osiguranje privremenim mjerama, u načelu tijekom brakorazvodnoga postupka, obrazlažući svoju odluku odgovarajućom primjenom odredaba Ovršnog zakona ${ }^{10}$ o privremenim mjerama radi

7 Riječ je o Zakonu o općem upravnom postupku iz 1956., Službeni list FNRJ, br. 52/56.; Službeni list SFRJ, br. 10/65., 18/65. - pročišćeni tekst, 4/77., 11/78., 32/78. - pročišćeni tekst, 9/86., 16/86. - ispravak, 47/86. - pročišćeni tekst.

8 V. u Mira Alinčić et al., Obiteljsko pravo (Zagreb: Narodne novine, 2001.), 120.

9 V. u Mira Alinčić et al., Obiteljsko pravo, (Zagreb: Narodne novine, 2007.), 96.

10 Riječ je o Ovršnom zakonu iz 1996., Narodne novine, br. 57/96., 29/99., 42/00., 173/03., 
osiguranja nenovčanih tražbina. ${ }^{11}$ Međutim, bilo je i suprotne sudske prakse. Tako, prema izraženom stajalištu jednoga drugostupanjskog suda, za određivanje privremene mjere primjenom odredaba OZ-a nužno je postojanje tražbine (novčane ili nenovčane) jedne stranke prema drugoj koja se osigurava. ${ }^{12}$ Dok prema shvaćanju toga suda takve tražbine nema kad sud odlučuje o načinu susreta i druženja djeteta i roditelja s kojim dijete ne živi. ${ }^{13}$ Prema njemu, riječ je o specifičnom odnosu roditelja i djeteta, o pravu i interesu maloljetnog djeteta da živi sa svojim roditeljima, odnosno da se druži i održava susrete $\mathrm{s}$ roditeljem s kojim ne živi. ${ }^{14}$ Stoga se o navedenim pitanjima ne može niti odlučivati određivanjem privremene mjere, $i$ to odgovarajućom primjenom odredaba OZ-a, već se o tome trebalo odlučivati u posebnom izvanparničnom postupku u skladu s odredbama čl. 100. i 101. ObZ-a 2003..$^{15}$

Donošenjem ObZ-a 2015. hrvatski zakonodavac vratio se normativnom pristupu ZBPO-a, propisivanjem posebnih sudskih postupaka osiguranja privremenim mjerama o tome s kojim će roditeljem, odnosno drugom osobom dijete stanovati te o ostvarivanju osobnih odnosa s djetetom. Postupak osiguranja privremenom mjerom o tome s kojim će roditeljem, odnosno drugom osobom dijete stanovati i o ostvarivanju osobnih odnosa s djetetom, propisan je u ObZ-u 2015. primjenom više metoda. Najprije su izdvojena pravila koja su opća za sve obiteljske i statusne sudske postupke, parnične, izvanparnične, ovršne te asekuracijske postupke (čl. 345.-367. ObZ 2015.). Zatim su izdvojena pravila koja su opća samo za posebne postupke osiguranja privremenim mjerama (čl. 530.-535. ObZ 2015.) te su za postupak osiguranja privremenom mjerom o tome s kojim će roditeljem, odnosno drugom osobom dijete stanovati i o ostvarivanju osobnih odnosa s djetetom, sadržana posebna pravila (čl. 536. ObZ 2015.). U tim je postupcima propisana i supsidijarna primjena OZ-a, a potom i Zakona o parničnom postupku ${ }^{16}$ (arg. ex čl. 21. OZ), ako drukčije nije određeno ObZ-om 2015. (čl. 346. ObZ 2015.).

Iako ObZ 2015. obuhvaća posebnu glavu koja se odnosi na posebne postupke osiguranja te izrijekom prepoznaje osiguranje privremenom mjerom o tome s kojim će roditeljem, odnosno drugom osobom dijete stanovati i o ostvarivanju osobnih odnosa s djetetom, otvaraju se (i dalje) određena načelno teorijska, ali i implementacijskopraktična pitanja. Ponajprije treba istaknuti ona koja se općenito odnose na dopuštenost

194/03., 151/04., 88/05., 121/05., 67/08., 139/10., 154/11., 12/12., 70/12, odnosno o novom Ovršnom zakonu iz 2012., Narodne novine, br. 112/12., 25/13. - v. čl. 101. Zakona o izmjenama i dopunama Zakona o parničnom postupku, 93/14., 55/16., 73/17. (dalje: OZ).

11 Za sudsku praksu prema ObZ-u 2003., v. u Branka Rešetar, Pravna zaštita prava na susrete $i$ druženje u obiteljskom pravu: doktorska disertacija (Zagreb: Pravni fakultet Sveučilišta u Zagrebu, 2008.), 299.

12 ŽS BJ, Gž-278/2009-2 od 26. ožujka 2009.

13 ŽS BJ, Gž-278/2009-2 od 26. ožujka 2009.

14 ŽS BJ, Gž-278/2009-2 od 26. ožujka 2009.

15 ŽS BJ, Gž-278/2009-2 od 26. ožujka 2009.

16 Zakon o parničnom postupku, Službeni list SFRJ, br. 4/77. - 35/91.; Narodne novine, br. 26/91., 53/91., 91/92., 112/99., 88/01. - v. čl. 50. Zakona o arbitraži, 117/03., 88/05. - v. čl. 129. Zakona o izmjenama i dopunama Ovršnog zakona, 2/07., 84/08., 96/08. - v. odluku USRH od 20. prosinca 2006. i 9. srpnja 2008., 123/08. - ispravak, 57/11., 148/11. - pročišćeni tekst, 25/13., 89/14. - v. odluku USRH od 11. srpnja 2014., 70/19. 
ovog pravozaštitnog puta, poput onih je li uopće dopušteno regulacijskim privremenim mjerama uređivati pojedine sadržaje roditeljske skrbi, njezina ostvarivanja i ostvarivanja osobnih odnosa s djetetom; jesu li te mjere dopuštene samo u odnosu na provizorno uređenje pitanja stanovanja djeteta, ili ostvarivanja i drugih sadržaja roditeljske skrbi; je li dopušteno privremenom mjerom odrediti zabranu ostvarivanja osobnih odnosa; je li dopušteno privremenom mjerom odrediti ostvarivanja osobnih odnosa djeteta sa srodnicima i drugim bliskim osobama iz čl. 120. ObZ-a 2015.; jesu li dopuštene privremene mjere u postupku radi određivanja mjera za zaštitu osobnih prava i dobrobiti djeteta; je li dopušteno privremenim mjerama provizorno urediti pitanje stanovanja djeteta u nekretnini koja predstavlja bračnu stečevinu roditelja itd. Povezano s time, kao što upozorava sudska praksa, otvoreno je općenito i pitanje pretpostavaka za određivanje tih privremenih mjera o pojedinim sadržajima roditeljske skrbi, njezina ostvarivanja i ostvarivanja osobnih odnosa s djetetom. Tomu treba pridodati i probleme uz određivanje stranaka tih postupaka, pitanja u odnosu na položaj djeteta te njegovo pravo na izražavanje mišljenja u postupcima osiguranja. Nužno je istaknuti i položaj centra za socijalnu skrb u postupku osiguranja, odnosno upitno je proizlazi li iz načelne odredbe čl. 536. st. 6. ObZ-a 2015. o ovlasti i obvezi centra da dade mišljenje u tim postupcima i pravo centra na žalbu protiv odluke o privremenim mjerama. Uz to, kako tumačiti odredbu čl. 536. st. 6. ObZ-a 2015. o obvezi suda da sasluša roditelje djeteta u kontekstu načelne žurnosti tih postupaka, kao i odredbu čl. 531. st. 1. ObZ-a 2015. o mogućnosti određivanja privremene mjere bez održavanja usmene rasprave itd.

U radu se nastoje raspraviti otvorena pitanja određivanja osiguranja privremenim mjerama o pojedinim sadržajima roditeljske skrbi, njezina ostvarivanja i ostvarivanja osobnih odnosa s djetetom, uzimajući u obzir sudsku praksu koja se (već) javila u primjeni ObZ-a 2015. U tom kontekstu, u drugom dijelu rada, koji slijedi uvodno određenje, raspravljaju se i analiziraju pitanja dopuštenosti toga pravozaštitnog puta (v. infra ad 2.). Potom slijedi dio o sudionicima postupka (v. infra ad 3.) te određenim pitanjima postupka osiguranja privremenim mjerama o pojedinim sadržajima roditeljske skrbi, njezina ostvarivanja i ostvarivanja osobnih odnosa s djetetom (v. infra ad 4.). U zaključnom dijelu rada dana je sinteza glavnih rezultata istraživanja (v. infra ad 5.).

\section{OSIGURANJE PRIVREMENIM MJERAMA: PITANJE DOPUŠTENOSTI PRAVOZAŠTITNOG PUTA}

\subsection{Postavljanje problema}

U odjeljku 2. glave V. o posebnim postupcima osiguranja, ObZ 2015. poimenice propisuje samo osiguranje privremenom mjerom o tome s kojim će roditeljem, odnosno drugom osobom dijete stanovati i o ostvarivanju osobnih odnosa s djetetom. Ako u stvarima o osobnim pravima djeteta, koje se odnose na pitanje s kojim će roditeljem, odnosno drugom osobom dijete stanovati i o ostvarivanju osobnih odnosa s djetetom, nije moguće postići sporazum, sud može po službenoj dužnosti ili na zahtjev djeteta ili 
roditelja odlučiti o tome privremenom mjerom (čl. 536. st. 1. ObZ 2015.). Riječ može biti o kognicijskom, parničnom ili izvanparničnom postupku u kojem se odlučuje o osobnim pravima djeteta, poput postupka u sporu o roditeljskoj skrbi i ostvarivanju osobnih odnosa ili o posebnom ovršnom postupku, poput postupka radi predaje djeteta ili ostvarivanja osobnih odnosa s djetetom (arg. ex čl. 530. st. 4., čl. 536. st. 1. ObZ 2015.). Međutim, ObZ 2015. među odredbama o mjerama za zaštitu osobnih prava i dobrobiti djeteta izrijekom prepoznaje i osiguranje privremenom mjerom o mirovanju ostvarivanja roditeljske skrbi, a koja se može odrediti u incidentalnom adhezijskom postupku uz izvanparnični postupak radi lišenja prava na roditeljsku skrb. ${ }^{17}$

Kao novinu u odnosu na ObZ 2003., ObZ 2015. propisuje institut mirovanja ostvarivanja roditeljske skrbi zbog pravnih ili stvarnih zapreka. Sud će u izvanparničnom postupku na prijedlog djeteta, roditelja ili centra za socijalnu skrb donijeti rješenje o mirovanju ostvarivanja roditeljske skrbi ako je roditelj odsutan i nepoznatog boravišta ili spriječen iz objektivnih razloga dulje vrijeme ostvarivati roditeljsku skrb (čl. 115. st. 1. ObZ 2015.). ${ }^{18}$ Također, sud može po službenoj dužnosti u izvanparničnom postupku radi određivanja mjere lišenja prava na roditeljsku skrb, ovisno o okolnostima slučaja, odrediti mirovanje roditeljske skrbi kao privremenu mjeru (čl. 173. u vezi s čl. 115. ObZ 2015.). Učinak rješenja o osiguranju privremenom mjerom mirovanja ostvarivanja roditeljske skrbi bio bi u tome da do pravomoćnosti rješenja o lišenju prava na roditeljsku skrb, odnosno drukčijeg načina okončanja tog postupka, ostvarivanje svih sadržaja roditeljske skrbi miruje, a skrb o djetetu se s obzirom na okolnosti slučaja povjerava drugoj osobi, ustanovi socijalne skrbi ili udomiteljskoj obitelji ( $\arg$. ex čl. 115. ObZ 2015.).

Uz to, ObZ 2015. sadrži i rješenja o određivanju osiguranja privremenim mjerama tijekom trajanja ovršnog postupka radi ostvarivanja osobnih odnosa $\mathrm{s}$ djetetom. Prema novim pravilima, u tom ovršnom postupku sud će prije donošenja rješenja o ovrsi zakazati ročište na kojemu će osobno saslušati stranke, kao i omogućiti djetetu izražavanje mišljenja, u cilju utvrđivanja relevantnih činjenica te ocjene svih okolnosti (čl. 522. st. 1. ObZ 2015.). ${ }^{19}$ Stoga, nakon što sasluša stranke, sud može na temelju ocjene svih okolnosti slučaja predložiti strankama da pristupe obiteljskoj medijaciji radi sporazumnog rješavanja spora (čl. 522. st. 2. ObZ 2015.). U slučaju ocjene potrebe stručne pripreme djeteta za ostvarivanje osobnih odnosa, posebice kod protivljenja djeteta njihovu ostvarivanju, sud treba uputiti dijete na stručni razgovor (čl. 522. st. 2., čl. 525. st. 1. ObZ 2015.). Ako je sud uputio dijete

17 O pojmu incidentalnih adhezijskih postupaka osiguranja u doktrini, v. u Mihajlo Dika, Građansko ovršno pravo, I. knjiga, Opće građansko ovršno pravo (Zagreb: Narodne novine, 2007.), 10 et seq.

18 Mirovanje ostvarivanja roditeljske skrbi zbog pravnih i stvarnih zapreka propisano je, uz određena odstupanja, po uzoru na odgovarajuća rješenja §§. 1673. i 1674. njemačkoga Građanskog zakonika iz 1896. (RGB1 S 195; verzija od 2. siječnja 2002., BGB1 2002 I 42, 2909; 2003 I 738). O tom institutu, v. i Dieter Schwab, Familienrecht, 17. izd. (München: Verlag C.H.Beck, 2009.), 344-346.

19 O novinama u obiteljskim ovršnim postupcima, v. u Branka Rešetar, „Privremena mjera i ovrha ostvarivanja osobnih odnosa s djetetom - razlozi promjena i nova rješenja“, u: Novo uređenje obiteljskih sudskih postupaka, ur. Jakša Barbić (Zagreb: HAZU, 2014.), 132-134. 
na stručni razgovor ili ako su stranke prihvatile obiteljsku medijaciju, odlukom može detaljnije precizirati ostvarivanje osobnih odnosa s djetetom tijekom trajanja stručnog razgovora ili obiteljske medijacije (čl. 522. st. 2. ObZ 2015.). Treba uzeti da je u navedenoj odredbi ObZ-a 2015. riječ o određivanju osiguranja privremenom mjerom o načinu ostvarivanja osobnih odnosa s djetetom tijekom trajanja ovršnog postupka (arg. ex čl. 522. st. 2. u vezi s čl. 536. st. 1. i 3. ObZ 2015.).

Unatoč navedenim rješenjima ObZ-a 2015. o osiguranju privremenim mjerama o ostvarivanju (pojedinih) sadržaja roditeljske skrbi i/ili osobnih odnosa s djetetom, pa i tijekom kognicijskog ili ovršnog postupka u obiteljskim stvarima, kao i propisivanju odgovarajuće primjene OZ-a (čl. 346. ObZ 2015.), u sudskoj se praksi javilo shvaćanje prema kojemu se osiguranje privremenim mjerama može određivati samo u skladu s odredbom čl. 529. st. 1. ObZ-a 2015. ${ }^{20} \mathrm{Uz}$ to, drugostupanjski je sud naveo i da se prvostupanjski sud pogrešno pozvao na odredbe čl. 347. st. 1. i 2. OZ-a, a koje propisuju vrste privremenih mjera radi osiguranja nenovčanih tražbina, među ostalim, i regulacijske privremene mjere. ${ }^{21}$ Drugostupanjski sud ističe da bi se mogla odrediti privremena mjera u skladu s odredbama OZ-a, potrebno je postojanje neke novčane ili nenovčane tražbine stranke. ${ }^{22}$ Sud dalje navodi da u tom postupku nije riječ o spornom odnosu između stranaka međusobno, a istodobno dolazi u kontradikciju, isticanjem da je riječ o pravima i interesima njihova maloljetnog djeteta u odnosu na koje između njih ne postoji sporazum. ${ }^{23}$ Također, drugostupanjski sud zaključuje i da je riječ o specifičnom pravnom odnosu između roditelja i djece koji je uređen odredbama ObZ-a 2015.24

Prema postavkama navedenog shvaćanja drugostupanjskog suda privremena mjera mogla bi se odrediti samo u odnosu na pitanje o tome s kojim će roditeljem dijete stanovati i o ostvarivanju osobnih odnosa s djetetom te o njegovu uzdržavanju. ${ }^{25} \mathrm{U}$ tim je postupcima bila riječ o potrebi upisa djeteta u osnovnu školu, i to tako da to u ime i za račun djeteta učini samo jedan od roditelja. ${ }^{26}$ Prema tumačenju drugostupanjskog suda, trebalo je primijeniti odredbe čl. 413. st. 1. t. 1. i st. 2. t. 3. ObZ-a 2015., prema kojima će sud u presudi kojom se utvrđuje da brak ne postoji ili se poništava ili razvodi te u drugim slučajevima razdvojenog života roditelja, po službenoj dužnosti odlučiti s kojim će roditeljem dijete stanovati, o ostvarivanju roditeljske skrbi i osobnih odnosa djeteta s roditeljem te uzdržavanju djeteta, a može i odrediti mjeru za zaštitu prava i dobrobiti djeteta kad je to prema okolnostima slučaja potrebno. ${ }^{27}$ Stoga je prema stajalištu drugostupanjskog suda, sud prvog stupnja trebao postupiti kao u povodu prijedloga za određivanje mjere za zaštitu prava i dobrobiti djeteta. ${ }^{28}$ Dalje, drugostupanjski sud navodi da okolnost što je prvostupanjski sud odredio privremenu

20 ŽS ZG, Gž Ob-1265/2016 od 11. listopada 2016; ŽS ZG, Gž Ob-1164/2016 od 27. rujna 2016.

21 ŽS ZG, Gž Ob-1265/2016 od 11. listopada 2016.; ŽS ZG, GŽ Ob-1164/2016 od 27. rujna 2016.

22 ŽS ZG, Gž Ob-1164/2016 od 27. rujna 2016.

23 ŽS ZG, Gž Ob-1164/2016 od 27. rujna 2016.

24 ŽS ZG, GŽ Ob-1164/2016 od 27. rujna 2016.

25 ŽS ZG, GŽ Ob-1265/2016 od 11. listopada 2016.; ŽS ZG, Gž Ob-1164/2016 od 27. rujna 2016.

26 ŽS ZG, Gž Ob-1265/2016 od 11. listopada 2016.; ŽS ZG, Gž Ob-1164/2016 od 27. rujna 2016.

27 ŽS ZG, Gž Ob-1265/2016 od 11. listopada 2016.; ŽS ZG, Gž Ob-1164/2016 od 27. rujna 2016.

28 ŽS ZG, Gž Ob-1265/2016 od 11. listopada 2016.; ŽS ZG, Gž Ob-1164/2016 od 27. rujna 2016. 
mjeru izrijekom pozivajući se na $\mathrm{OZ}$, a ne mjeru u skladu s odredbom čl. 413. st. 2. t. 3. ObZ-a 2015., ne dovodi u pitanje pravilnost i zakonitost pobijane odluke. ${ }^{29}$

Zanimljivo je izdvojiti i shvaćanje drugostupanjskog suda prema kojemu izbor pravila postupka prema kojima će sud postupati, kognicijskog izvanparničnog postupka u kojem se odlučuje o ostvarivanju osobnih odnosa s djetetom ili pak postupka osiguranja privremenom mjerom radi ostvarivanja osobnih odnosa s djetetom, ovisi o činjenicama na kojima je prijedlog kojim se pokreće postupak utemeljen.$^{30} \mathrm{U}$ tom postupku, pobijanim prvostupanjskim rješenjem zabranjeno je ostvarivanje osobnih odnosa protustranke s maloljetnim djetetom u skladu s prethodnom presudom, i to za vrijeme dok traje epidemija bolesti COVID-19. ${ }^{31}$ Prema shvaćanju drugostupanjskog suda, prvostupanjski je sud donio pobijano rješenje pravilno ocjenjujući da je riječ o izvanparničnom (kognicijskom) postupku radi ostvarivanja osobnih odnosa $\mathrm{s}$ djetetom, i to o zabrani ostvarivanja osobnih odnosa s djetetom (čl. 478. st. 4. t. 3., čl. 123. st. 1. ObZ 2015.), a ne o posebnom postupku osiguranja privremenom mjerom o ostvarivanju osobnih odnosa s djetetom (čl. 536. ObZ 2015.), s obrazloženjem da „činjenice na kojima je predmetni prijedlog utemeljen upravo upućuju na to“.32

\subsection{Analiza sudskih odluka}

Opisane odluke drugostupanjskih sudova (v. supra ad 2.1.) negiraju mogućnost osiguranja privremenim mjerama o ostvarivanju drugih sadržaja roditeljske skrbi, mimo pitanja s kojim će roditeljem, odnosno drugom osobom dijete stanovati, primjenom odredaba čl. 536. ObZ-a 2015., uz odgovarajuću primjenu odredaba OZa, i to posebice one o određivanju regulacijskih privremenih mjera (čl. 347. st. 2. OZ). Umjesto toga, iz izraženog shvaćanja suda proizlazi inzistiranje na primjeni pravila kognicijskog (izvanparničnog) postupka o ostvarivanju pojedinih sadržaja roditeljske skrbi i osobnih odnosa s djetetom.

Tako je sud zauzeo stav da u slučaju reguliranja pitanja zastupanja djeteta pri upisu u osnovnu školu treba primijeniti pravozaštitni put koji je propisan u odredbi čl. 413. st. 2. t. 3. ObZ-a 2015., a ne posebni postupak osiguranja privremenom mjerom. ${ }^{33}$ Iz toga, dalje, proizlazi da bi sud o pitanju zastupanja djeteta pri upisu u osnovnu školu zapravo trebao odlučivati prema pravilima kognicijskog (izvanparničnog) postupka, i to prema izričitoj uputi drugostupanjskog suda, onoga koji se odnosi na mjere za zaštitu osobnih prava i dobrobiti djeteta. Pritom treba primijetiti da ObZ 2015. poimence ne propisuje takvu mjeru čiji bi sadržaj bio zastupanje djeteta po samo jednom roditelju koji ostvaruje roditeljsku skrb, među mjerama za zaštitu osobnih prava i dobrobit djeteta. ${ }^{34} \mathrm{~S}$ druge strane, za odlučivanje o tim pitanjima, ostvarivanja pojedinih sadržaja roditeljske skrbi, pa i zastupanja djeteta, u slučaju izostanka

29 ŽS ZG, Gž Ob-1164/2016 od 27. rujna 2016.

30 ŽS ST, Gž Ovr Ob-31/2020-4 od 15. svibnja 2020.

31 ŽS ST, Gž Ovr Ob-31/2020-4 od 15. svibnja 2020.

32 ŽS ST, Gž Ovr Ob-31/2020-4 od 15. svibnja 2020.

33 ŽS ZG, Gž Ob-1265/2016 od 11. listopada 2016.; ŽS ZG, Gž Ob-1164/2016 od 27. rujna 2016.

34 O mjerama za zaštitu osobnih prava i dobrobiti djeteta iz nadležnosti suda, v. čl. 149. ObZ-a 2015. 
sporazuma roditelja, propisan je posebni izvanparnični postupak radi ostvarivanja pojedinih sadržaja roditeljske skrbi. ${ }^{35}$

Od izbora pravozaštitnog puta, posebnog izvanparničnog postupka radi ostvarivanja pojedinih sadržaja roditeljske skrbi i/ili osobnih odnosa s djetetom (čl. 478. ObZ 2015.) ili posebnog postupka osiguranja privremenom mjerom o pojedinim sadržajima roditeljske skrbi, njezina ostvarivanja i ostvarivanju osobnih odnosa, uključujući i zabranu njihova ostvarivanja (čl. 536., čl. 173. u vezi s čl. 115. ObZ 2015.), ovise i daljnja materijalnopravna i postupovnopravna pitanja. Među ostalim, treba istaknuti pretpostavke koje je potrebno utvrditi, odgovarajuću razinu dokaznog standarda (izvjesnost ili vjerojatnost), provizornost uređenja odnosa između roditelja i djece regulacijskom privremenom mjerom, odnosno potrebu opravdanja osiguranja privremenom mjerom pokretanjem odgovarajućeg sudskog postupka u određenom roku itd. Uz to, bitno je istaknuti i nužnost sudjelovanja stranaka u postupku obveznog savjetovanja kao posebnu procesnu pretpostavku dopuštenosti kognicijskog (izvanparničnog) postupka o ostvarivanju pojedinih sadržaja roditeljske skrbi i osobnih odnosa (čl. 322. ObZ 2015.).

Unatoč navedenim odlukama drugostupanjskih sudova koje negiraju mogućnost osiguranja (regulacijskim) privremenim mjerama o pojedinim sadržajima roditeljske skrbi, njezina ostvarivanja i ostvarivanja osobnih odnosa, ističu se i one koje prihvaćaju takvu mogućnost uređivanja odnosa roditelja i djece. Tako je drugostupanjski sud potvrdio prvostupanjsko rješenje kojim se određuje osiguranje privremenom mjerom oduzimanja prava roditelju da stanuje s djetetom te je svakodnevna skrb o djetetu povjerena udomiteljskoj obitelji, uz određivanje ostvarivanja osobnih odnosa djeteta s roditeljem. ${ }^{36}$ Opisanu privremenu mjeru prvostupanjski sud je obrazložio okolnostima da prikupljena činjenična građa ne daje dostatnu osnovu za odlučivanje o prijedlogu centra za socijalnu skrb, već je potrebno utvrditi relevantne činjenice u daljnjem tijeku izvanparničnog postupka u odnosu na propisane pretpostavke za određivanje predložene mjere zaštite osobnih prava i dobrobiti djeteta. ${ }^{37}$ Pritom se sud izrijekom pozvao na odgovarajuću primjenu OZ-a, i to na odredbu i propisane pretpostavke za određivanje regulacijskih privremenih mjera (čl. 347. st. 2. OZ), kao i na odredbu ObZ-a 2015. o oficijelnim ovlastima i dužnostima suda da odredi privremenu mjeru u svakom postupku koji je u tijeku o pravima i dobrobiti djeteta (čl. 530. st. 4. ObZ 2015.). ${ }^{38}$

U drugoj odluci drugostupanjski je sud potvrdio prvostupanjsko rješenje o privremenoj mjeri kojom je, među ostalim, određeno pravo stanovanja jednog roditelja sa zajedničkom maloljetnom djecom u obiteljskom domu koji predstavlja bračnu stečevinu. ${ }^{39}$ Pritom je sud drugog stupnja naveo da je prvostupanjski sud pravilno ocijenio da je predlagatelj osiguranja učinio vjerojatnim da je predložena mjera nužna kako bi se spriječilo nasilje u obitelji stranaka, te da je pravilnom primjenom materijalnog prava, i to pozivom na odredbe ObZ-a 2015. (čl. 46. st. 2.,

35 V. čl. 478. st. 1. ObZ-a 2015.

36 ŽS ZG, Gž Ob-263/2018 od 5. ožujka 2018.

37 V. u ŽS ZG, Gž Ob-263/2018 od 5. ožujka 2018.

38 ŽS ZG, Gž Ob-263/2018 od 5. ožujka 2018.

39 ŽS ZG, Gž Ob-477/2017 od 2. svibnja 2017. 
čl. 346.) te odgovarajuću primjenu OZ-a (čl. 346. st. 1. t. 2.), odlučio da tijekom njezina trajanja predlagatelj osiguranja i maloljetna djeca imaju pravo stanovanja u zajedničkoj nekretnini stranaka. ${ }^{40} \mathrm{Uz}$ to, drugostupanjski sud ocjenjuje da je pravilno, u skladu s odredbom čl. 532. st. 1. ObZ-a 2015., predlagatelju osiguranja naloženo da u određenom roku opravda privremenu mjeru pokretanjem postupka. ${ }^{41}$

\subsection{Vlastiti stav o dopuštenosti osiguranja privremenim mjerama te pretpostavkama za njegovo odredivanje}

Prema odredbi čl. 536. st. 1. ObZ-a 2015., ako se u stvarima o osobnim pravima djeteta, koje se odnose na pitanje s kojim će roditeljem, odnosno drugom osobom dijete stanovati i o ostvarivanju osobnih odnosa s djetetom, ne može postići sporazum, sud može po službenoj dužnosti ili na zahtjev djeteta ili roditelja odlučiti o tome privremenom mjerom. Iako se navedena odredba ObZ-a 2015. odnosi na osiguranje određivanjem privremene mjere o tome s kojim će roditeljem, odnosno drugom osobom dijete stanovati i/ili o ostvarivanju osobnih odnosa s djetetom, uključujući i zabranu ostvarivanja osobnih odnosa $\mathrm{s}$ djetetom $\mathrm{u}$ incidentalnom adhezijskom postupku uz postupak u stvarima o osobnim pravima djeteta kao glavni, treba uzeti da bi se ona na odgovarajući način primjenjivala i na slučajeve pokretanja samostalnog postupka osiguranja tom privremenom mjerom (arg. ex čl. 529. st. 2. u vezi s čl. čl. 536. st. 1. i 3. ObZ 2015.). Stoga bi se i prije pokretanja odgovarajućega sudskog postupka u kojem bi se odlučivalo o osobnim pravima djeteta moglo odrediti osiguranje privremenom mjerom o tome s kojim će roditeljem, odnosno drugom osobom dijete stanovati i/ili o ostvarivanju osobnih odnosa s djetetom, uključujući i zabranu ostvarivanja osobnih odnosa s djetetom (arg. ex čl. 529. ObZ 2015.).

U odredbama čl. 536. ObZ-a 2015. riječ je u osnovi o regulacijskim privremenim mjerama jer se njima provizorno uređuje odnos među strankama, roditeljima $i$ djetetom. ${ }^{42}$ Pritom je objekt te privremene mjere trajniji pravni odnos, odnosno njezin je cilj osiguranje konkretnoga pravnog odnosa između roditelja i djeteta, iz kojeg mogu proizaći tražbine koje se mogu prisilno ostvarivati. Stoga je dvojbeno shvaćanje koje se javilo u sudskoj praksi, prema kojemu je za određivanje privremenih mjera potrebno postojanje neke novčane ili nenovčane tražbine stranke, odnosno da u postupcima radi provizornog uređenja ostvarivanja pojedinih sadržaja roditeljske skrbi nije riječ o spornom odnosu između stranaka međusobno, već o pravima i interesima njihova maloljetnog djeteta u odnosu na koje između roditelja ne postoji sporazum. ${ }^{43}$

Uz poimenice određenu privremenu mjeru o tome s kojim će roditeljem, odnosno drugom osobom dijete stanovati i o ostvarivanju osobnih odnosa s djetetom, ObZ 2015. izrijekom propisuje i osiguranje privremenom mjerom o mirovanju ostvarivanja

40 ŽS ZG, Gž Ob-477/2017 od 2. svibnja 2017.

41 ŽS ZG, Gž Ob-477/2017 od 2. svibnja 2017.

42 O regulacijskim privremenim mjerama u općem ovršnom pravu, v. u Mihajlo Dika, Građansko ovršno pravo, I. knjiga, Opće građansko ovršno pravo, 888-893; Gabrijela Mihelčić, u suradnji s Damirom Kontrecom, Komentar Ovršnog zakona s opsežnom sudskom praksom i abecednim kazalom pojmova (Zagreb: Organizator, 2015.), 1044.

43 V. supra ad 1. i 2.1. 
roditeljske skrbi, i to $\mathrm{u}$ incidentalnom adhezijskom postupku uz izvanparnični postupak radi određivanja mjere lišenja prava na roditeljsku skrb (čl. 173. u vezi s čl. 115. ObZ 2015.). Stoga treba zaključiti da, prema ObZ-u 2015., sadržaj osiguranja privremenom mjerom može biti provizorno određenje roditelja, odnosno druge osobe s kojom će dijete stanovati i/ili način ostvarivanja osobnih odnosa s djetetom i/ili zabrana njihova ostvarivanja ( $\arg$. ex čl. 536. st. 1. i 3. ObZ 2015.), ali i provizorno određenje mirovanja ostvarivanja svih sadržaja roditeljske skrbi (arg. ex čl. 173. u vezi s čl. 115. ObZ 2015.). Polazeći od odredbe čl. 173. ObZ-a 2015. o sadržaju regulacijske privremene zaštite, treba uzeti da bi se osiguranje privremenom mjerom moglo odnositi na sve sadržaje roditeljske skrbi i njezina ostvarivanja te ostvarivanja osobnih odnosa s djetetom (arg. a maiori ad minus ex čl. 173. ObZ 2015.). Budući da se provizorno uređenje ostvarivanja pojedinih sadržaja roditeljske skrbi i/ili osobnih odnosa sastoji u privremenom određivanju pojedinih prava i obveza roditelja $u$ odnosu na dijete, treba uzeti da se, uz regulacijsku privremenu mjeru, može odrediti i privremena mjera radi osiguranja tih (novčanih ili nenovčanih) tražbina. ${ }^{44}$

Analizirajući sadržaj regulacijske zaštite privremenim mjerama o ostvarivanju pojedinih sadržaja roditeljske skrbi i osobnih odnosa s djetetom, može se uočiti da se podudara s privremenim mjerama radi osiguranja nenovčanih tražbina. U obiteljskim postupcima osiguranja, privremena mjera u načelu bi se sastojala $u$ normiranju, uređenju odnosa među strankama (poput, pitanja s kojim će roditeljem dijete stanovati ili ostvarivanju osobnih odnosa), ali bi mogla biti riječ i o naredbama, odnosno zabranama (poput, zabrane ostvarivanja osobnih odnosa) i/ili svojevrsnim dopuštenjima (poput, dopuštenja jednom od roditelja da poduzme samostalno neku radnju u ime djeteta: upiše dijete $u$ školu, promijeni adresu prebivališta/boravišta $i$ sl. ${ }^{45}$ Pritom funkcija privremenih mjera o tome s kojim će roditeljem, odnosno drugom osobom dijete stanovati i/ili o ostvarivanju osobnih odnosa, uključujući i zabranu ostvarivanja osobnih odnosa $\mathrm{s}$ djetetom, općenito o (ne)ostvarivanju pojedinih sadržaja roditeljske skrbi, može biti preventivnog i/ili represivnog karaktera, ovisno o tome je li pravo tek ugroženo i/ili već povrijeđeno. Uz to, zaštitu bi u povodu njih bilo moguće tražiti i određivati u načelu u povodu konstitutivnih zahtjeva.

Na rješenja ObZ-a 2015., koja se općenito odnose na pojedina pitanja određivanja osiguranja privremenim mjerama te ona o privremenoj mjeri o tome s kojim će roditeljem, odnosno drugom osobom dijete stanovati i o ostvarivanju osobnih odnosa s djetetom, uz određena odstupanja, očito su utjecale odgovarajuće odredbe njemačkoga Zakona o postupku u obiteljskim stvarima i stvarima dobrovoljne sudbenosti (dalje: FamFG). ${ }^{46}$ Tako u općim odredbama, FamFG propisuje određena pitanja uz osiguranje privremenim mjerama $u$ obiteljskim stvarima, $i$ to vrste

44 Tako je prvostupanjski sud odredio da će protivniku osiguranja biti izrečena novčana kazna u iznosu do $30.000,00 \mathrm{kn}$ (čl. 16. st. 1. OZ) ako se bude ponašao suprotno obvezi na trpljenje da njegovo dijete ostvaruje pravo na stanovanje u nekretnini koja je u njegovu suvlasništvu u skladu s rješenjem o privremenoj mjeri. V. u ŽS ZG, Gž Ob-477/2017 od 2. svibnja 2017.

45 Usp. u odnosu na opće ovršno pravo, Mihajlo Dika, Građansko ovršno pravo, I. knjiga, Opće građansko ovršno pravo, 892-893.

46 Gesetz über das Verfahren in Familiensachen und in den Angelegenheiten der freiwilligen Gerichtsbarkeit iz 2008. godine, BGB1 I S 2587. 
privremenih mjera, regulacijske privremene mjere, nadležnost suda, prijedlog za određivanje mjere, odlučivanje o privremenoj mjeri bez održavanja usmene rasprave, opravdanje privremene mjere pokretanjem sudskoga postupka u glavnoj stvari, ovrhu i promptnu ovršnost u stvarima zaštite od nasilja, ukidanje ili izmjenu rješenja o privremenim mjerama, odgodu ovrhe odluke o privremenim mjerama te pravne lijekove (§§. 49.-57. FamFG). ${ }^{47} \mathrm{Uz}$ to, posebna je odredba o privremenim mjerama sadržana u odjeljku o postupku u stvarima koje se odnose na djecu (§. 157. FamFG), a koja ističe obvezu suda ispitati potrebu određivanja privremenih mjera. Općenito, privremene mjere prema FamFG-u mogu se određivati u svim obiteljskim stvarima $(\S .111 . \text { FamFG) })^{48}$

Uz njemački FamFG, i austrijski Savezni zakon o sudskom postupku u izvanparničnim pravnim stvarima (dalje: AußStrG) ${ }^{49}$ prepoznaje mogućnost privremenog uređenja roditeljske skrbi ili prava na ostvarivanje osobnih odnosa ( $\S$. 107. st. 2. AußStrG). Prema odgovarajućim rješenjima austrijskog prava dopušteno je privremeno urediti roditeljsku skrb ili pravo na susrete i druženja ako postoji aktualna i ozbiljna opasnost za dobrobit djeteta..$^{50}$

Prema hrvatskom OZ-u, sud može odrediti mjeru kojom će privremeno urediti sporni odnos među strankama ako je to nužno: (1.) radi sprječavanja nastanka nenadoknadive ili teško nadoknadive štete, (2.) nasilja ili (3.) ako je iz drugih važnih razloga to potrebno radi osiguranja pravnoga reda (čl. 347. st. 2. OZ). Pritom treba uzeti da pretpostavka nužnosti za osiguravanjem pravnoga reda iz drugih važnih razloga postoji, odnosno da se njezino postojanje predmnijeva u slučajevima propisanim u odredbi čl. 536. st. 2. ObZ-a 2015.

Sud će dakle odrediti osiguranje privremenom mjerom o ostvarivanju pojedinih sadržaja roditeljske skrbi i/ili osobnih odnosa s djetetom, uključujući i zabranu njihova ostvarivanja, uzimajući u obzir sve okolnosti slučaja: (1.) ako nije moguće postići sporazum među strankama o tim pitanjima te (2.1.) kad stranke uputi da pristupe prvom sastanku obiteljske medijacije (čl. 338., čl. 416. st. 2., čl. 417. st. 1., čl. 522. st. 2. ObZ 2015.) ili (2.2.) kad naloži stručnu procjenu, odnosno vještačenje (čl. 416. st. 1. ObZ 2015.). Uz kumulativno ispunjenje navedenih dviju pretpostavaka, pri čemu je potonja postavljena alternativno, treba uzeti da Zakon predmnijeva i nužnosti određivanja privremenih mjera u cilju osiguranja, među ostalim, pravnoga reda. $\mathrm{U}$ ostalim slučajevima obiteljskih postupaka osiguranja, treba uzeti da bi pretpostavke osiguranja privremenom mjerom postojale kad bi se na razini vjerojatnosti dokazalo da je to nužno radi sprječavanja nastanka nenadoknadive ili teško nadoknadive štete,

47 V. u Theodor Keidel, FamFG: Kommentar zum Gesetz über das Verfahren in Familiensachen und die Angelegenheiten der freiwilligen Gerichtsbarkeit, 16. izd. (München: C. H. Beck, 2009.), 516-552.

48 V. Theodor Keidel, FamFG: Kommentar zum Gesetz über das Verfahren in Familiensachen und die Angelegenheiten der freiwilligen Gerichtsbarkeit, 518.

49 Bundesgesetz über das gerichtliche Verfahren in Rechtsangelegenheiten außer Streitsachen iz 2003. godine, BGB1 I 2003/111.

50 V. Walter H. Rechberger, Kommentar zum Außerstreitgesetz (Wien/New York: Springer, 2006.), 334-335; Susanne Beck, Kindschaftsrecht (Wien: Manzsche Verlags- und Universitätsbuchhandlung, 2009.), 397. 
nasilja (u obitelji) ili da to zahtijeva potreba za osiguranjem pravnoga reda, pritom uzimajući u obzir kod pretpostavke pravnoga reda i načelo i standarde zaštite dobrobiti djeteta (arg. ex čl. 347. st. 2. OZ u vezi s čl. 348. st. 1. ObZ 2015.). ${ }^{51}$

Analizirajući pretpostavke za određivanje privremenih mjera kojima se provizorno uređuje odnos između roditelja i djeteta, razina vjerojatnosti koja je potrebna za njihovo utvrđenje, okolnost da se u određenim slučajevima predmnijeva nužnost njihova određivanja, dvojbena je sudska praksa koja negira mogućnost ovog pravozaštitnog puta, odnosno inzistira na kognicijskom (u načelu, izvanparničnom) postupku, u kojem se odlučuje o ostvarivanju pojedinih sadržaja roditeljske skrbi i osobnih odnosa, odnosno njihovoj zabrani. ${ }^{52}$ Inzistiranje na izvanparničnom postupku radi ostvarivanja pojedinih sadržaja roditeljske skrbi i osobnih odnosa s djetetom ujedno znači i inzistiranje na sudjelovanju stranaka u postupku obveznog savjetovanja prije pokretanja sudskoga postupka (arg. ex čl. 329. st. 1. ObZ 2015.), katkad i na prvom sastanku s obiteljskim medijatorom (arg. ex čl. 54. st. 3. i 4. u vezi s čl. 413. st. 1. ObZ 2015.), na dokaznom standardu izvjesnosti pri uređenju odnosna djeteta $i$ roditelja itd. Takvo shvaćanje u osnovi lišava stranke njihovog prava na provizornu regulacijsku pravnu zaštitu kakva joj se pruža u posebnom obiteljskom postupku osiguranja privremenom mjerom.

\section{SUDIONICI POSTUPKA OSIGURANJA}

\subsection{Sud}

U postupku osiguranja privremenim mjerama u obiteljskim stvarima granice interne jurisdikcije utvrđene su pravilima ObZ-a 2015. o pravnim stvarima za koje je izrijekom rečeno da će u njima sudovi određivati privremene mjere (čl. 173., čl. 529. st. 1., čl. 530. ObZ 2015.). Općinski sudovi stvarno su nadležni u određivanju i provođenju osiguranja ( $\arg$. ex čl. 18. t. 1. Zakona o sudovima; $; 3$ čl. 292. st. 1. OZ).

Za određivanje privremene mjere o tome s kojim će roditeljem, odnosno drugom osobom dijete stanovati, odnosno o ostvarivanju roditeljske skrbi i osobnih odnosa s djetetom, (relativno) je nadležan sud koji je nadležan za odlučivanje o pravu koje se osigurava privremenom mjerom (čl. 530. st. 1. ObZ 2015.). ${ }^{54}$ Različito od opće odredbe čl. 340. OZ-a, ObZ 2015. ne propisuje razliku, po pitanju mjesne nadležnosti, ako se tražbina osigurava prije pokretanja odgovarajućega sudskog postupka o tom

51 Odbor za prava djeteta prema UN Konvenciji o pravima djeteta (1989.), razvio je trojaki koncept najboljeg interesa djeteta: kao supstancijalno (materijalno) pravo, kao fundamentalno, interpretativno pravno načelo te kao pravilo postupka. V. t. 6. Committee on the Rights of the Child, General comment No. 14 (2013) on the right of the child to have his or her best interests taken as a primary consideration (art. 3, para. 1) (Geneva, 2013.). Također, o tzv. child-centered approachu koji položaj djeteta i njegova prava stavlja u središte postupaka, v. i u Noam Peleg, „International Children's Rights Law: General Principles“, u: International Human Rights of Children, eds. Ursula Kilkelly i Ton Liefaard (Singapore: Springer, 2019.), 151-153.

52 V. supra ad 1. i 2.1.

53 Zakon o sudovima, Narodne novine, br. 28/13., 33/15., 82/15., 82/16., 67/18., 126/19.

54 Slično rješenje sadržano je u njemačkom FamFG-u (§. 50. st. 1.). 
pravu ili nakon što je on pokrenut. Za izmjenu, ali treba uzeti i ukidanje privremene mjere, nadležan je sud koji je donio odluku, osim ako je predmet ustupljen drugom sudu (čl. 534. st. 2. ObZ 2015.).

U žurnim slučajevima privremenu mjeru može odrediti i onaj sud na čijem je području nastala potreba za određivanjem privremene mjere ili na čijem se području nalazi osoba, odnosno stvar na koju će se odnositi privremene mjere (čl. 530. st. 2. ObZ 2015.). Pritom je propisano da će taj sud koji je odredio mjeru u žurnim slučajevima, ustupiti predmet sudu koji je inače nadležan za njezino određivanje u skladu s odredbom čl. 530. st. 1. ObZ-a 2015. (čl. 530. st. 3. ObZ 2015.). ${ }^{55}$

Treba primijetiti da navedene opće odredbe čl. 530. st. 1.-3. ObZ-a 2015. o nadležnosti za privremene mjere u obiteljskim stvarima propisuju nadležnost suda za „određivanje“ privremene mjere. Stoga će se mjesna nadležnost za provedbu privremenih mjera određivati uz odgovarajuću primjenu odredaba OZ-a (arg. ex čl. 346. ObZ 2015.). Prema odredbi čl. 340. st. 1. OZ-a, za provedbu privremene mjere mjesno je nadležan sud koji bi bio mjesno nadležan za provedbu ovrhe. ${ }^{56}$

Postupak osiguranja privremenim mjerama u obiteljskim stvarima u prvom i drugom stupnju vodi i odluke donosi sudac pojedinac (arg. ex čl. 346. ObZ 2015.; čl. 10. st. 1. OZ). Pritom ako se o osiguranju nekih tražbina, odnosno prava odlučuje u parničnom ili nekom drugom sudskom postupku, takve odluke sud donosi u sastavu u kojemu vodi taj sudski postupak (čl. 10. st. 2. OZ).

\subsection{Stranke}

Stranke postupka osiguranja privremenom mjerom o tome s kojim će roditeljem, odnosno drugom osobom dijete stanovati, odnosno o ostvarivanju roditeljske skrbi i/ ili osobnih odnosa s djetetom, uključujući i zabranu njihova ostvarivanja, su dijete i roditelji koji ostvaruju roditeljsku skrb, odnosno osobne odnose (arg. ex čl. 536. st. 1., 4.-6., čl. 173. u vezi s čl. 115. ObZ 2015.). Ako bi se privremenom mjerom provizorno određivalo da će dijete stanovati kod druge osobe (npr. udomitelja), treba uzeti da je i ta druga osoba stranka (incidentalnog adhezijskog) postupka osiguranja u kojem se određuje privremena mjera (arg. ex čl. 536. st. 1. ObZ 2015.). Uz to, kad bi se u postupku osiguranja određivala privremena mjera o ostvarivanju osobnih odnosa djeteta sa srodnicima, odnosno drugim bliskim osobama, i osoba o čijem se pravu na ostvarivanje osobnih odnosa odlučuje privremenom mjerom također bi bila stranka postupka osiguranja (arg. ex čl. 120. ObZ 2015.).

ObZ 2015. propisuje mogućnost imenovanja posebnog skrbnika djetetu u postupku osiguranja. Ako su interesi djeteta i roditelja u suprotnosti, dijete u postupku osiguranja zastupa posebni skrbnik kojeg imenuje centar za socijalnu skrb. Ako je djetetu imenovan posebni skrbnik, prestaju ovlaštenja roditelja na zastupanje djeteta u tom postupku (čl. 536. st. 4. ObZ 2015.).

U načelu će uvijek postojati suprotnost interesa kod (regulacijskih) privremenih

55 Slično rješenje o nadležnosti suda u žurnim slučajevima sadrži i njemački FamFG (§. 50. st. 2.).

56 ObZ 2015. propisuje mjesnu nadležnost u postupku ovrhe radi predaje djeteta (čl. 512. st. 2. i 3.), u postupku ovrhe radi ostvarivanja osobnih odnosa s djetetom (čl. 520.) te u postupku ovrhe radi uzdržavanja (čl. 526.). 
mjera o tome s kojim će roditeljem dijete stanovati i o ostvarivanju osobnih odnosa s djetetom, odnosno njihovoj zabrani. Polazi se od toga da nema sporazuma među strankama, odnosno da je odnos koji treba osigurati sporan (arg. ex 536. st. 1. ObZ 2015.). Stoga bi načelno trebalo optirati za zastupanje djeteta putem posebnog skrbnika u postupku osiguranja odnosa djeteta i roditelja privremenom mjerom. Uz to, u tim slučajevima, kad je riječ o adhezijskom određivanju osiguranja privremenom mjerom, dijete bi (već) trebalo biti zastupano putem posebnog skrbnika u kognicijskom postupku u sporu o roditeljskoj skrbi ( $\arg$. ex čl. 240. st. 1. t. 2., čl. 414. st. 2. ObZ 2015.). ${ }^{57}$

U postupcima osiguranja privremenom mjerom o ostvarivanju roditeljske skrbi i osobnih odnosa propisana je i načelna obveza suda da omogući djetetu izražavanje mišljenja, kao i da sasluša roditelje (čl. 536. st. 5. i 6. ObZ 2015.). Sud bi mogao odustati od utvrđivanja mišljenja djeteta, odnosno od saslušanja roditelja ako za to postoje posebno opravdani razlozi, odnosno ako to zahtijevaju posebne okolnosti slučaja (arg. ex čl. 360. st. 4., čl. 362. st. 3. ObZ 2015.). Međutim, u tim slučajevima, treba uzeti da bi sud bio obvezan o razlozima, odnosno o posebnim okolnostima slučaja zbog kojih se ne utvrđuje mišljenje djeteta, odnosno roditelj ne saslušava, sastaviti službenu bilješku u spisu te ih obrazložiti u svojoj odluci (arg. a cohaerentia, a completudine ex čl. 360. st. 4. ObZ 2015.). Treba uzeti, da postoji i načelna obveza suda da sasluša i druge osobe na koje će se izravno odnositi pravi učinci odluke o privremenoj mjeri (npr. osobe kod koje bi dijete trebalo stanovati) (arg. ex čl. 536. st. 1. i 6., čl. 363. ObZ 2015.).

Ako sud ne bi saslušao dijete ili roditelje u postupcima osiguranja u kojima oni sudjeluju kao stranke te u kojima se osigurava ostvarivanje pojedinih sadržaja roditeljske skrbi i/ili osobnih odnosa, a da za to nema posebnih okolnosti slučaja, radilo bi se o bitnoj povredi odredaba postupka osiguranja ( $\arg$. ex čl. 536. st. 5. i 6. ObZ 2015.; čl. 21. OZ; čl. 354. st. 2. t. 6. ZPP). Također, promatrajući saslušanje djeteta i roditelja i kao dokazno sredstvo, moglo bi se raditi i o pogrešno ili nepotpuno utvrđenom materijalnopravno relevantnom činjeničnom stanju kao žalbenom razlogu (arg. ex čl. 21. OZ; 355. ZPP), odnosno i o mogućoj bitnoj povredi odredaba postupka osiguranja koja se odnosi na okolnosti da odluka nema razloge o odlučnim činjenicama (arg. ex čl. 21. OZ; čl. 354. st. 2. t. 11. ZPP).

\subsection{Posebno o centru za socijalnu skrb}

U postupcima osiguranja privremenom mjerom o tome s kojim će roditeljem, odnosno drugom osobom dijete stanovati, odnosno o ostvarivanju roditeljske skrbi i/ili osobnih odnosa s djetetom, uključujući i zabranu njihova ostvarivanja, sud je obvezan zatražiti mišljenje centra za socijalnu skrb kao pomoćnog tijela (arg. ex čl. 356. t. 3., čl. 536. st. 6. ObZ 2015.). Međutim, iz navedenih rješenja o centru

57 Sud drugog stupnja ističe da u slučaju postupka za izmjenu odluke s kojim roditeljem će dijete stanovati i o ostvarivanju osobnih odnosa s djetetom, koji je pokrenut od strane roditelja s kojim maloljetna djeca ne stanuju, je očito da su interesi djeteta i roditelja u suprotnosti. Stoga sud zaključuje da je bilo nužno imenovati maloljetnoj djeci posebnog skrbnika u skladu s odredbom čl. 536. st. 4. ObZ-a 2015. ŽS ZG, Gž Ob-547/2017 od 22. svibnja 2017. 
za socijalnu skrb kao pomoćnom tijelu suda u postupcima osiguranja privremenom mjerom o ostvarivanju roditeljske skrbi i osobnih odnosa s djetetom, ne proizlazi i pravo centra na žalbu protiv rješenja donesenog u tom postupku.

Treba uzeti u obzir da centar za socijalnu skrb ima pravo na žalbu protiv rješenja donesenog u postupku osiguranja, onda ako i inače ima položaj stranke u parničnom, ili izvanparničnom (kognicijskom) ili ovršnom postupku u kojem se odlučuje o tom pravu, odnosno ostvarivanju pojedinih sadržaja roditeljske skrbi i/ili osobnih odnosa, ili njihovom ograničenju, oduzimanju, mirovanju ili zabrani (arg. ex čl. 354. st. 2. t. 4.-7. i 10. ObZ 2015.). U tim postupcima u kojima ima položaj stranke, centar je ovlašten iznositi činjenice koje druge stranke nisu navele, predlagati dokaze i podnositi pravne lijekove (čl. 354. st. 3. ObZ 2015.).

\section{ODREĐENA PITANJA POSTUPKA OSIGURANJA}

U općim odredbama ObZ-a 2015. obuhvaćena su posebna načela obiteljskih i statusnih sudskih postupaka, tako i obiteljskih postupaka osiguranja. Na području obiteljskog ovršnog prava i prava osiguranja vrijede također načela općeg ovršnog prava i prava osiguranja. ${ }^{58}$ Načelo žurnosti, opće načelo ovršnog prava i prava osiguranja (čl. 13. OZ), posebice je istaknuto u posebnim obiteljskim postupcima ovrhe i osiguranja propisivanjem rokova za donošenje i otpremu prvostupanjske i drugostupanjske odluke (čl. 347. st. 4.-6. ObZ 2015.).

Sud je obvezan tijekom postupka osobito paziti da se zaštite prava i interesi djece (čl. 348. st. 1. ObZ 2015.), a koja je načelna dužnost suda u posebnim postupcima osiguranja o ostvarivanju roditeljske skrbi i osobnih odnosa, dalje precizirana putem odredaba o imenovanju posebnog skrbnika i omogućavanju djetetu da izrazi svoje mišljenje te, općenito, isključivanjem javnosti u tim postupcima (čl. 351. ObZ 2015.), kao i rješenjem o objavi odluka s prikrivenim osobnim podatcima na e-oglasnoj ploči suda (čl. 367. st. 1. ObZ 2015.).

Žurnost i zaštita dobrobiti djeteta postiže se i odredbom čl. 535. ObZ-a 2015. Prema navedenoj odredbi, žalba protiv odluke o privremenoj mjeri ne odgađa ovrhu, ali i općim odredbama o neposrednoj dostavi, odnosno elektroničkoj komunikaciji sudova i drugih javnih tijela (centra za socijalnu skrb ili Centra za posebno skrbništvo) (čl. 365. st. 1. ObZ 2015.). Bitno je i rješenje iz čl. 533. ObZ-a 2015. kojim se znatno (privremeno) odstupa od načela saslušanja stranaka u cilju žurnosti postupka i zaštite dobrobiti djeteta. Prema njemu se odluka o privremenoj mjeri može provesti i prije nego što je ona dostavljena protivnoj stranci, dakle, protivniku osiguranja, $u$ slučajevima postojanja obiteljskog nasilja ili u slučaju drugih otežavajućih okolnosti (čl. 533. ObZ 2015.). ${ }^{59} \mathrm{U}$ tim je slučajevima, dakle, odluka o privremenoj mjeri djelotvorna s njezinim donošenjem.

58 O općim načelima, v. u Mihajlo Dika, Građansko ovršno pravo, I. knjiga, Opće građansko ovršno pravo, 43-81.

59 Tako ako bi se prethodnom dostavom rješenja o privremenoj mjeri mogla onemogućiti njegova ovrha te bi time nastupila povreda prava, odnosno odnosa koji se osigurava tom mjerom. V. Theodor Keidel, FamFG: Kommentar zum Gesetz über das Verfahren in Familiensachen und die Angelegenheiten der freiwilligen Gerichtsbarkeit, 539. 
U posebnim obiteljskim postupcima osiguranja načelo oficijelnosti naglašeno je odredbama ObZ-a 2015. prema kojima je sud ovlašten po službenoj dužnosti odrediti privremene mjere u svakom postupku koji je u tijeku, a u kojem se odlučuje o pravima i dobrobiti djeteta (arg. ex čl. 173., čl. 530. st. 4., čl. 536. st. 1. ObZ 2015.). U tim obiteljskim asekuracijskim postupcima istaknuto je i istražno načelo tako da je sud ovlašten utvrđivati i činjenice koje stranke nisu iznijele, a može odlučiti da se dokazuju i činjenice koje su stranke priznale u postupku (čl. 350. ObZ 2015.).

Sud može o privremenoj mjeri o ostvarivanju roditeljske skrbi i osobnih odnosa odlučiti i bez održavanja usmene rasprave (čl. 531. st. 1. ObZ 2015.), a što bi bilo važno kod obiteljskoj nasilja ili drugih otežavajućih okolnosti. I inače je načelo pismenosti određujuće u postupcima ovrhe i osiguranja (čl. 7. OZ), a čime se nastoji doprinijeti žurnosti tih postupaka. ${ }^{60}$ Stoga bi o ocjeni suda ovisilo održavanje ročišta, odnosno sud bi ga održao onda kad bi smatrao da je to svrhovito (arg. ex čl. 7. st. 2. OZ). O ročištu, umjesto zapisnika, sudac može sastaviti službenu bilješku (čl. 7. st. 3. OZ). Izostanak jedne ili obje stranke te sudionika s ročišta, ili njihovo neodazivanje pozivu suda radi saslušanja, ne sprječava sud da i dalje postupa (čl. 7. st. 5. OZ). Međutim, i onda kad je odlučio da neće održavati ročišta, sud može izvan ročišta saslušati stranku ili sudionika u postupku ako je to predviđeno zakonom, kao u slučaju odredbe čl. 536. st. 5. i 6. ObZ-a 2015. o izražavanju mišljenja djeteta, odnosno saslušanju roditelja i pribavljanju mišljenja centra za socijalnu skrb, ili ako smatra da je to potrebno radi razjašnjenja pojedinih pitanja ili očitovanja o nekom prijedlogu stranke (čl. 7. st. 4. $\mathrm{OZ})$.

ObZ 2015., među općim odredbama, propisuje nesuspenzivnost žalbe protiv rješenja o privremenoj mjeri (čl. 535. ObZ 2015.). U nedostatku rješenja o daljnjim značajkama pravnih lijekova protiv rješenja u obiteljskim postupcima osiguranja, primjenjivale bi se na odgovarajući način odredbe OZ-a (arg. ex čl. 346. ObZ 2015.; čl. 11.-12., čl. 352. OZ). Također, ako se privremene mjere o ostvarivanju sadržaja roditeljske skrbi ili osobnih odnosa određuju u incidentalnom adhezijskom postupku uz glavni kognicijski ili ovršni postupak, za koji ObZ 2015. nema posebne odredbe o žalbi protiv rješenja o privremenoj mjeri, rješenje o privremenoj mjeri moglo bi se pobijati žalbom prema odredbama OZ-a (arg. ex čl. 346. ObZ 2015.; čl. 11., čl. 352. $\mathrm{OZ})^{61}$

\section{ZAKLJUČAK}

Obiteljsko ovršno pravo i pravo osiguranja, posebice nakon donošenja ObZ-a 2015., razvija se kao posebni i samostalni pravni sustav kojim se na specifični način uređuju procesnopravni i materijalnopravni odnosi koji se javljaju tijekom i u povodu tih posebnih obiteljskih postupaka. ObZ 2015., uz šire normiranje općih pitanja određivanja osiguranja privremenim mjerama u obiteljskim odnosima, (ponovno) je

60 Usp. §. 51. st. 2. njemačkoga FamFG-a; v. Theodor Keidel, FamFG: Kommentar zum Gesetz über das Verfahren in Familiensachen und die Angelegenheiten der freiwilligen Gerichtsbarkeit, 530.

61 Usp. Mihajlo Dika, Građansko ovršno pravo, I. knjiga, Opće građansko ovršno pravo, 894. 
propisao i osiguranje privremenom mjerom o tome s kojim će roditeljem, odnosno drugom osobom dijete stanovati i o ostvarivanju osobnih odnosa s djetetom, odnosno njihovoj zabrani. Uz tu poimenice određenu mjeru osiguranja, ObZ 2015. izrijekom propisuje i osiguranje privremenom mjerom o mirovanju ostvarivanja svih sadržaja roditeljske skrbi u incidentalnom adhezijskom postupku uz izvanparnični postupak radi određivanja mjere lišenja prava na roditeljsku skrb. Stoga treba zaključiti da, prema ObZ-u 2015., sadržaj osiguranja privremenom mjerom može biti provizorno određenje roditelja, odnosno druge osobe s kojom će dijete stanovati i/ili način ostvarivanja osobnih odnosa $\mathrm{s}$ djetetom $\mathrm{i} / \mathrm{ili}$ zabrana njihova ostvarivanja, ali $\mathrm{i}$ provizorno određenje mirovanja ostvarivanja svih sadržaja roditeljske skrbi.

Različito od pojedinih shvaćanja sudova koja su analizirana u radu (v. supra ad 2.), a polazeći osobito od odredbe čl. 173. ObZ-a 2015. o sadržaju privremene regulacijske zaštite, treba uzeti da bi se osiguranje privremenom mjerom moglo odnositi na sve sadržaje roditeljske skrbi i njezina ostvarivanja te ostvarivanja osobnih odnosa s djetetom. Budući da se provizorno uređenje ostvarivanja pojedinih sadržaja roditeljske skrbi i/ili osobnih odnosa sastoji u privremenom određivanju pojedinih prava i obveza roditelja u odnosu na dijete, treba uzeti da je uz regulacijsku privremenu mjeru moguće odrediti i privremenu mjeru radi osiguranja tih (novčanih i nenovčanih) tražbina. Također, treba istaknuti da je vidljiv utjecaj njemačkoga FamFG-a i njegovih rješenja na odredbe ObZ-a 2015. koje se odnose na pojedina pitanja određivanja privremenih mjera $\mathrm{u}$ obiteljskim odnosima. $\mathrm{U}$ tom pravnom sustavu privremene mjere, uključujući i regulacijske privremene mjere, mogu se općenito određivati u svim obiteljskim stvarima, dok je posebnim rješenjem FamFG-a sadržanim u odjeljku o postupku u stvarima koje se odnose na djecu, istaknuta i obveza suda ispitati potrebu određivanja privremenih mjera u tim stvarima.

Zaključno, od izbora pravozaštitnog puta, (kognicijskog) parničnog ili izvanparničnog postupka radi ostvarivanja pojedinih sadržaja roditeljske skrbi i/ili osobnih odnosa s djetetom ili posebnog obiteljskog postupka osiguranja privremenom mjerom, ovise i daljnja materijalnopravna i postupovnopravna pitanja. Među ostalim, nužno je istaknuti pretpostavke koje je potrebno utvrditi, odgovarajuću razinu dokaznog standarda, provizornost uređenje odnosa između roditelja i djece regulacijskom privremenom mjerom, odnosno potrebu opravdanja osiguranja privremenom mjerom pokretanjem odgovarajućeg sudskog postupka u određenom roku, nužnost sudjelovanja stranaka u postupku obveznog savjetovanja kao posebnoj procesnoj pretpostavci dopuštenosti kognicijskog postupka o ostvarivanju pojedinih sadržaja roditeljske skrbi i osobnih odnosa itd. Stoga odbijanje mogućnosti osiguranja privremenim mjerama o ostvarivanju (pojedinih) sadržaja roditeljske skrbi i/ili osobnih odnosa s djetetom, odnosno inzistiranje na kognicijskom postupku radi ostvarivanja pojedinih sadržaja roditeljske skrbi i osobnih odnosa, ujedno znači i inzistiranje na sudjelovanju stranaka u postupku obveznog savjetovanja prije pokretanja sudskoga postupka, katkad i na prvom sastanku s obiteljskim medijatorom, na dokaznom standardu izvjesnosti pri uređenju odnosna djeteta i roditelja ili prava na ostvarivanje osobnih odnosa s drugim srodnicima itd. Takvo shvaćanje u osnovi lišava stranke njihovog prava na provizornu regulacijsku pravnu zaštitu kakva im se pruža u postupku osiguranja. 


\section{LITERATURA}

1. Alinčić, Mira i Ana Bakarić. Porodično pravo, 3. izd. Zagreb: Narodne novine, 1989.

2. Alinčić, Mira, Ana Bakarić Abramović, Dubravka Hrabar, Dijana Jakovac-Lozić i Aleksandra Korać. Obiteljsko pravo. Zagreb: Narodne novine, 2001.

3. Alinčić, Mira, Dubravka Hrabar, Dijana Jakovac-Lozić i Aleksandra Korać Graovac. Obiteljsko pravo, 3. izd. Zagreb: Narodne novine, 2007.

4. Beck, Susanne. Kindschaftsrecht. Wien:Manzsche Verlags- und Universitätsbuchhandlung, 2009.

5. Bundesgesetz über das gerichtliche Verfahren in Rechtsangelegenheiten außer Streitsachen iz 2003. godine, BGB1 I 2003/111.

6. Bürgerliches Gesetzbuch iz 1896., RGB1 S 195, verzija od 2. siječnja 2002., BGB1 2002 I 42, 2909; 2003 I 738.

7. Committee on the Rights of the Child. General comment No. 14 (2013) on the right of the child to have his or her best interests taken as a primary consideration (art. 3, para. 1). Geneva, 2013.

8. Dika, Mihajlo. Građansko ovršno pravo, I. knjiga, Opće građansko ovršno pravo. Zagreb: Narodne novine, 2007.

9. Gesetz über das Verfahren in Familiensachen und in den Angelegenheiten der freiwilligen Gerichtsbarkeit iz 2008. godine, BGB1 I S 2587.

10. Keidel, Theodor. FamFG: Kommentar zum Gesetz über das Verfahren in Familiensachen und die Angelegenheiten der freiwilligen Gerichtsbarkeit, 16. izd. München: C. H. Beck, 2009.

11. Mihelčić, Gabrijela, u suradnji s Damirom Kontrecom. Komentar Ovršnog zakona s opsežnom sudskom praksom i abecednim kazalom pojmova. Zagreb: Organizator, 2015.

12. Obiteljski zakon iz 1998., Narodne novine, br. 162/98.

13. Obiteljski zakon iz 2003., Narodne novine, br. 116/03., 17/04., 136/04., 107/07., 57/11. v. čl. 52. Zakona o izmjenama i dopunama Zakona o parničnom postupku, 61/11., 25/13. - v. čl. 100. Zakona o izmjenama i dopunama Zakona o parničnom postupku, 5/15. - v. Rješenje USRH, br. U-I-3101/2014 i dr. od 12. siječnja 2015.

14. Obiteljski zakon iz 2015., Narodne novine, br. 103/15., 98/19., 47/20. - v. čl. 35. Zakona o Centru za posebno skrbništvo.

15. Ovršni zakon iz 1996., Narodne novine, br. 57/96., 29/99., 42/00., 173/03., 194/03., 151/04., 88/05., 121/05., 67/08., 139/10., 154/11., 12/12., 70/12.

16. Ovršni zakon iz 2012., Narodne novine, br. 112/12., 25/13. - v. čl. 101. Zakona o izmjenama i dopunama Zakona o parničnom postupku, 93/14., 55/16., 73/17.

17. Peleg, Noam „International Children's Rights Law: General Principles“. U: International Human Rights of Children, eds. Ursula Kilkelly i Ton Liefaard, 135-157. Singapore: Springer, 2019.

18. Rechberger, Walter H. Kommentar zum Außerstreitgesetz. Wien/New York: Springer, 2006.

19. Rešetar, Branka. Pravna zaštita prava na susrete i druženje u obiteljskom pravu: doktorska disertacija. Zagreb: Pravni fakultet Sveučilišta u Zagrebu, 2008.

20. Rešetar, Branka. „Privremena mjera i ovrha ostvarivanja osobnih odnosa s djetetom razlozi promjena i nova rješenja“. U: Novo uređenje obiteljskih sudskih postupaka, ur. Jakša Barbić, 121-134. Zagreb: Hrvatska akademija znanosti i umjetnosti, 2014.

21. Schwab, Dieter. Familienrecht, 17. izd. München: Verlag C.H.Beck, 2009.

22. Triva, Siniša. Građansko parnično procesno pravo, 4. izd. Zagreb: Narodne novine, 1980.

23. Zakon o braku i porodičnim odnosima SR Hrvatske iz 1978., Narodne novine SRH, br. 11/78., 27/78. - ispravak, 45/89., 51/89. - pročišćeni tekst, 59/90.

24. Zakon o općem upravnom postupku iz 1956., Službeni list FNRJ, br. 52/56.; Službeni list SFRJ, br. 10/65., 18/65. - pročišćeni tekst, 4/77., 11/78., 32/78. - pročišćeni tekst, 9/86., 16/86. - ispravak, 47/86. - pročišćeni tekst. 
25. Zakon o parničnom postupku, Službeni list SFRJ, br. 4/77. - 35/91.; Narodne novine, br. 26/91., 53/91., 91/92., 112/99., 88/01. - v. čl. 50. Zakona o arbitraži, 117/03., 88/05. - v. čl. 129. Zakona o izmjenama i dopunama Ovršnog zakona, 2/07., 84/08., 96/08. - v. odluku USRH od 20. prosinca 2006. i 9. srpnja 2008., 123/08. - ispravak, 57/11., 148/11. - pročišćeni tekst, 25/13., 89/14. - v. odluku USRH od 11. srpnja 2014., 70/19.

26. Zakon o sudovima, Narodne novine, br. 28/13., 33/15., 82/15., 82/16., 67/18., 126/19.

27. ŽS BJ, Gž-278/2009-2 od 26. ožujka 2009.

28. ŽS ST, Gž Ovr Ob-31/2020-4 od 15. svibnja 2020.

29. ŽS ZG, Gž Ob-263/2018 od 5. ožujka 2018.

30. ŽS ZG, Gž Ob-477/2017 od 2. svibnja 2017.

31. ŽS ZG, Gž Ob-547/2017 od 22. svibnja 2017.

32. ŽS ZG, Gž Ob-1164/2016 od 27. rujna 2016.

33. ŽS ZG, Gž Ob-1265/2016 od 11. listopada 2016. 


\author{
Slađana Aras Kramar*
}

Summary

\title{
PROVISIONAL MEASURES ON EXERCISING PARENTAL CARE AND PERSONAL RELATIONS WITH THE CHILD - SOME LEGAL CONTROVERSIES
}

With the adoption of the Family Act of 2015, the Croatian legislator returned to the normative approach of the 1978 Marriage and Family Relations Act, explicitly prescribing special court security procedures for issuing temporary measures on whom parent or other person the child will live with and on exercising personal relations with the child. In addition, the Act prescribes in a more comprehensive manner certain general issues regarding the determination of temporary measures in family law relations. Nevertheless, certain theoretical, but also implementation-practical issues still arise, especially regarding the admissibility of this provisional legal protection in the case of legal relations between parents and children, which are in the paper analysed and discussed. The final part of the paper contains a summary synthesis of the main research results.

Keywords: security procedure; temporary measures; parental care; Family Act; Enforcement Act.

* Slađana Aras Kramar, Ph.D., Associate Professor, Faculty of Law, University of Zagreb; saras@ pravo.hr. ORCID: https://orcid.org/0000-0002-8908-775X. 
